DOI : $10.14746 /$ pp.2015.20.2.9

Katarzyna M. CWYNAR

Rzeszów

\title{
Środki masowego przekazu w kulturze współczesnej - informacja i oświecenie czy manipulacja?
}

\begin{abstract}
Streszczenie: W tekście autorka formułuje tezę, że współcześnie została zatracona rola dziennikarstwa polegająca na przekazie informacji o wydarzeniach oraz popularyzacji wiedzy i formułowaniu pozytywnych wzorców kulturowych. Stało się to na skutek odejścia od kultury odwolującej się do wartości. Współczesne środki masowego przekazu kreują kulturę konsumpcyjna, nastawioną na doraźne interesy i życie potocznością. Umożliwia ona w imię interesów różnych grup manipulowanie społeczeństwem. Warunkiem przezwyciężenia tego niekorzystnego dla spoleczeństwa stanu rzeczy jest powrót do ideałów Oświecenia i kultury odwołującej się do wartości.
\end{abstract}

Słowa kluczowe: media masowe, manipulacja, kultura, wartości, interesy

\section{Uwagi wstępne. Postawienie problemu}

Drzyjmuje się, że środki masowego przekazu ${ }^{1} \mathrm{w}$ centralistycznych, autorytarnych czy wręcz totalitarnych systemach politycznych z założenia podporządkowane są działaniom politycznym. Przedstawiciele mediów, o ile akceptują wówczas panujący porządek polityczny, treścią przekazów wyrażają interesy rządzących. W swoich publikacjach odwolują się nie tylko do faktów i opinii przedstawianych zgodnie z bieżącymi interesami rządzących, ale także do akceptowanej aksjologii politycznej, którą wyraża przyjęta ideologia. Funkcję ideologii w konkretnych wypadkach pełni filozofia np. marksizm, liberalizm, globalizm itp., bądź też światopogląd np. nacjonalizm, kosmopolityzm, progresizm, ateizm, agnostycyzm itp., czy też religia lub moralność. $W$ tego rodzaju systemach przekazy medialne w swej intencjonalności nakierowane są na kształtowanie określonej - zgodnie z przyjętą aksjologią - świadomości politycznej obywateli. Oznacza to, iż indywidualność poszczególnych jednostek jest formowana na użytek państwa i przyjętego systemu politycznego. Nie tylko to, co publiczne, społeczne, ale także w wyznaczonym zakresie to, co jednostkowe i prywatne staje się wówczas polityczne (państwowe, tj. należące do państwa i jedynie mogące być prezentowane przez aparat państwowy i zgodnie $\mathrm{z}$ jego interesem). W konsekwencji następuje upolitycznienie życia jednostki i społeczeństwa we wszystkich możliwych jego sferach publicznych. $Z$ tym związane jest także ograniczenie wolności i brak możliwości formułowania niezależnych opinii.

\footnotetext{
${ }^{1}$ Inaczej media masowe. Pojęciem tym, zwłaszcza rozumianym szeroko, obejmuje się zarówno prasę, radio, telewizję, internet, ale także kino, czy też film, plakat, reklamę, mural itp.
} 
Te, jeśli już funkcjonuja, to jako publikacje mediów nielegalnych (przykładowo jako tzw. prasa podziemna, literatura drugiego obiegu itp.).

Czy można jednakże stwierdzić, iż w przeciwieństwie do systemów niedemokratycznych media społeczeństw funkcjonujących na zasadach demokracji, w tym odwołujących się do doktryny liberalizmu, wolne są od tendencyjnego przekazu informacji? Czy tym samym nie podlegają one, jeśli nie żadnym, to co najmniej znaczącym naciskom grup interesów politycznych czy też ekonomicznych? Jest to także pytanie o to: czy w tzw. systemach demokratycznych media masowe nie są stosowane jako narzędzie manipulacji? Pytanie to jest tym bardziej zasadne, gdyż przyjmuje się, że o ile w społeczeństwach totalitarnych media służą propagandzie i manipulacji, to w społeczeństwach demokratycznych koncentrują się one na przekazie wolnej od zafałszowań informacji. W tekście tym podejmę próbę analizy zasadności tej tezy, koncentrując się przede wszystkim na ewentualnych jej ograniczeniach.

Odwołując się chociażby do potocznej obserwacji życia publicznego, z dużym prawdopodobieństwem można przyjąć, że demokracja liberalna, w której wolność jako wartość uznaje się za podstawowy warunek jej funkcjonowania, bynajmniej automatycznie nie wyklucza możliwości manipulacji, a w efekcie indoktrynacji przy użyciu mediów nie tylko jednostek, ale i całych społeczeństw. Co więcej, jako system odwołujący się do liberalizmu, a zatem zakładający pluralizm interesów, zarówno o charakterze indywidualnym, jak i społecznym (w tym interesów politycznych, ekonomicznych, religijnych, a także innych), umożliwia, jeśli nie wręcz tworzy, warunki różnorodnego oddziaływania na poszczególne jednostki i grupy społeczne. W rzeczywistości możliwe jest sterowanie społeczeństwem $w$ taki sposób, aby realizowało ono niejednokrotnie cele niewynikające z potrzeb członków społeczeństwa i na rzecz ich dobra, lecz odpowiadające chociażby dysponentom tego rodzaju środków. Media w tych wypadkach służą - a wręcz są narzędziami - manipulacji. Przy tym, manipulowanie opinią społeczną jest stosowane nie tylko przez ośrodki polityczne, ale także przez różnego rodzaju grupy interesów ekonomicznych, militarnych, religijnych, światopoglądowych itp.

Jednocześnie należy podkreślić, że media masowe, bez względu na system polityczny sa jednak nie tylko narzędziem manipulowania społeczeństwem, ale wręcz warunkują funkcjonowanie społeczeństwa współczesnego, zarówno w jego wymiarze politycznym, ekonomicznym, jak i kulturowym. Są one bowiem środkiem szeroko rozumianej komunikacji kulturowej. Trudno byłoby wyobrazić sobie funkcjonowanie społeczeństwa współczesnego bez takich środków komunikowania masowego jak chociażby radio, telewizja czy też internet. Są one nie tylko konieczne dla życia społecznego, a nawet wręcz wyznaczają jego tożsamość. Pytanie o media masowe nie tyle zatem sprowadza się do ich potrzeby, ale do tego, czemu służą i czemu powinny służyć? W skrajnej formule można by je sformułować jako pytanie o to: czy w ogóle powinny czemukolwiek służyć poza rzetelną informacją? Jeśli zaś wskazać na niezależność/wolność jako jeden z warunków rzetelności informacji, wówczas należałoby zapytać również o to: czy w ogóle możliwa jest wolność mediów, a jeśli tak, to na czym miałaby ona polegać i w czym należałoby upatrywać granic jej zasadności? Inaczej mówiąc, pytanie to sprowadza się do kwestii granic wolności mediów w tzw. systemach demokratycznych (neoliberalnych). Zauważę przy tym, że odpowiedź na to pytanie, komplikuje się ze względu na relacje między wolnością mediów a rzetelnością informacji. Z jednej strony wolność (mediów) jest warun- 
kiem rzetelności informacji (mediów), z drugiej jednak może owa rzetelność nie tylko wolność ograniczać, ale wręcz wykluczać.

Dzieje się to w sytuacji, gdy przy zachowaniu zasady wolności wypowiedzi (wolności słowa), informacje przekształca się, a także fałszuje ze względu na interes prezentowany chociażby przez dysponentów mediów. W kapitalizmie wolnorynkowym (liberalizmie) ${ }^{2}$, wolność jako wartość została bowiem sprowadzona do wolności interesów. Środki masowego przekazu są w tym systemie jednym z jego elementów. Podlegają więc wszelkim uwarunkowaniom, jakim podlegają podmioty działań gospodarki i polityki wolnorynkowej. Przy tym należałoby dodać, że media masowe na wolnym rynku konkurencji informacji funkcjonują niejako w podwójnej roli. Są bowiem w jakiejś mierze zarówno wytwórcą informacji, ich kreatorem, jak i funkcjonują zgodnie ze znaczeniem pojęcia 'media' jako 'środki' ich przekazu. Niezależnie jednak od tego rozróżnienia, w obu wypadkach narażone są na działania w warunkach tzw. wolnego rynku, na wzajemną konkurencję, jak i grę interesów. Ta przy zachowaniu warunków wolnej konkurencji, jak można by sądzić, winna pozytywnie wpływać na jakość samych mediów, jak i przekazywanych przez nie treści. Problem jednak w tym, że z jednej strony sama konkurencja ulega istotnemu ograniczeniu, a w wypadku monopolizacji mediów przez tzw. koncerny medialne wolność ta staje się iluzoryczna. $Z$ drugiej strony konkurencja wolnorynkowa zachęca do „modelowania” przekazu, choćby z tego powodu by czynić go bardziej atrakcyjnym, a zatem „łatwym do sprzedania”, a także skutecznym dla ewentualnego oddziaływania. W tej sytuacji pojawia się pytanie o rolę dziennikarstwa, a właściwie dziennikarzy, w przekazie informacji. Jest to pytanie o to, na ile możliwe jest tzw. niezależne, czy też wolne dziennikarstwo realizujące ideę rzetelnego przekazu informacji?

\section{2. Środki masowego przekazu a wartości $i$ interesy}

Początków dziennikarstwa należałoby doszukiwać się w czasach nowożytnych. Warunkiem jego uformowania się jako nowej formy komunikowania społecznego było wynalezienie w Europie druku w XV wieku przez Johanna Gutenberga. Drukowane broszury informacyjne, jako trwalsze i identyczne w swej wielości egzemplarzy powielanych mechanicznie, stopniowo wyparły przepisywane ręcznie biuletyny. Niemniej jednak początkowo nie miały charakteru wydawnictw ciagłych. Pierwsze druki periodyczne w krajach Europy Zachodniej zaczęto wydawać znacznie później, bowiem dopiero w wieku XVII. Za jeden z pierwszych tego rodzaju uznaje się, drukowany w Niemczech, „Relation aller Fürnemmen und gedenckwürdigen Historien” (1605). Kolejnymi pierwowzorami periodycznych gazet informacyjnych był m.in. wydawany w Holandii „Courante uyt Italien, Duytslandt, \&c.” (1618), „Corante, or weekely newes from Italy, Germany, Hungary, Poland, Bohemia, France and the Low Countreys” w Anglii (1621), „La Gazette” we Francji (1631), a także „Gazzetta di Mantova” w Italii (1664). W Polsce pierwszą publikacją ukazującą się systematycznie, której celem był przekaz informacji, był „Mer-

\footnotetext{
${ }^{2}$ Obok kapitalizmu wolnorynkowego (resp. - liberalnego) funkcjonuje także pojęcie kapitalizmu społecznego czy też kapitalizmu socjalnego, uwzględniającego postulaty socjalizmu bądź też kooperatyzmu (przykładem może być tu choćby kapitalizm skandynawski).
} 
kuryusz Polski: dzieie wszytkiego świata w sobie zamykaiący dla informacyey pospolitey" wydawany w 1661 roku (Łojek, 1988, s. 14-15).

Działalność prasowo-wydawniczą tamtego czasu w znacznej mierze prowadzili drukarze i księgarze. Dziennikarstwo bowiem jako odrębna profesja w kulturze Zachodu uformowało się dopiero w wieku XVIII, a właściwie w czasach rewolucji francuskiej i wojen Napoleona. Był to czas wychodzenia z myślenia ukształtowanego w kulturze feudalnej, jednakże głęboko przenikniętej myśleniem religijnym, a więc myśleniem aksjologicznie wysoce skondensowanym (determinowanym wartościami). Ten sposób myślenia w jego zsekularyzowanej aksjologicznie formule kontynuowało myślenie nowożytne. Było to zatem myślenie zdominowane wartościami i ideami, a przede wszystkim wartością wiedzy (oświecenia), ideami wolności, równości, braterstwa, wyzwolenia ludu, demokracji. W warstwie aksjologicznej w XIX wieku zostało ono wzmocnione etosem romantyzmu. Wiek XVIII i XIX był także czasem dominacji w kulturze wartości poznawczych, dominacji wiedzy i czasem wiary w postęp zarówno techniczny, jak i społeczny. Była to epoka dominacji światopoglądu scjentystycznego i wiary w człowieka. Powstająca profesja dziennikarska w znacznym stopniu przejęła wówczas ten aksjologiczny sposób myślenia i działania praktycznego. Przejęła na siebie poczucie misji propagowania nowych idei, a dziennikarze rolę misjonarzy nowej wiary. To oni mieli iść w pierwszym szeregu ludzi niosących postęp.

Kultura wieku XX, już w pierwszej jego połowie, zaczęła odchodzić od aksjologii wieku oświecenia i wiarę w wartości poznawcze, i postęp zastępować pojęciem doraźnych korzyści i interesu. Wyrazem tego były obie wojny światowe toczone w imię interesów imperialnych, żądzy władzy i panowania ekonomicznego nad innymi. Kontynuacją tego sposobu myślenia jest także współczesny neoliberalizm i działanie wedle interesu. Myślenie to już pod koniec wieku XIX i na początku wieku XX swoje intelektualne uzasadnienie znalazło w filozofii życia W. Diltheya oraz F. Nietzschego, a także w propozycji nowego myślenia M. Heideggera. Pierwszy ze wskazanych myślicieli rzeczywistość kulturową sprowadził do życia, znajdując tym samym uzasadnienie dla wartości w instynktach i popędach oraz przeżyciach i emocjach, a więc w biologicznej strukturze bytu ludzkiego (Zachariasz, 1983, s. 34-35). F. Nietzsche formułuje wprost rezygnację z wartości na rzecz myślenia w kategoriach użyteczności (Marquard, 1994b, s. 3-4; Marquard, 1994a, s. 156), a M. Heidegger uznając myślenie wedle wartości za nieporozumienie opowiada się za myśleniem z „bycia”, czyli ze zdarzania, czy też jeszcze inaczej mówiąc, z tego, co „zdarza się”. W rezultacie dokonujących się zmian w sferze myślenia, a w konsekwencji i w sposobie bycia, czas wspólczesny w kulturze europejskiej to bynajmniej nie epoka wartości i idei, ale epoka interesów i konsumpcji dla samej konsumpcji, wygody i sybarytyzmu. Jest czasem myślenia i działania tym, co przynosi życie. Współczesne dziennikarstwo w swej masie jest jedynie funkcją tego czasu, jest takie jak cała kultura. Jeśli nawet zdarzają się odmienne postawy, to te funkcjonują na zasadzie wyjątku, odmienności od głównych nurtów, na peryferiach neoliberalnej - podporządkowanej pojęciu interesu - cywilizacji.

Współczesna kultura Zachodu wydaje się już nie tylko odchodzić od nowożytnej aksjologii etosu wiedzy i prawdy teoretycznej, a więc prawdy zdobywanej dla niej samej lecz pogrążać się w myśleniu pragmatycznym, jeśli nie wręcz praktycznym. Pragmatyzacja ta dotknęła nawet samego myślenia teoretycznego, w tym filozoficznego, i znalazła 
swój wyraz zarówno w rezygnacji z myślenia systemowego, jak i z filozofii tzw. pierwszych zasad, na rzecz pragmatyzmu i tzw. myślenia krótkiego ${ }^{3}$. Zrezygnowano z pytania poznawczego o tzw. istote, czyli o to: co to jest? Ważniejsze bowiem stały się pytania o to: jak to się robi?, czy też: jak to jest zrobione? (Zachariasz, 2009, s. 21-22; Zachariasz, 2011, s. 287-292), a przede wszystkim: czemu czy komu to służy?, komu jest to potrzebne? jak może być wykorzystane?, jakim i czyim interesom? Ten stan rzeczy szczególnie przydatny okazał się grupom interesu, a przede wszystkim dla interesów politycznych i ekonomicznych. Jednym z istotnych wyznaczników realizacji tego rodzaju interesów, zwłaszcza w wymiarze kształtowania opinii publicznej, przychylnej ich uskutecznieniu, są środki masowego przekazu: prasa, radio, telewizja, internet, a także kino, teatr, kabaret i z nimi zbieżne. Środki masowego przekazu, które wedle swego wcześniejszego wzorca, opartego na myśleniu ,wedle wartości”, miały pełnić funkcje informacyjne, oświatowe, wychowawcze, przyjęły rolę środków realizacji interesów politycznych, ekonomicznych itp. Informacje, służąc celom praktycznym, oceniane są przede wszystkim w kategoriach wartości użytkowej/ekonomicznej, przy jednoczesnym marginalizowaniu celów poznawczych i intelektualnych przekazywanych przez media treści. Oznacza to podporządkowanie warstwy informacyjnej przekazu wymogom interesów mocodawców. W konsekwencji prowadzi do dezinformacji i kształtowania „społeczeństwa niewiedzy". Należałoby dodać, że dzieje się to przy równoczesnym propagowaniu nie tylko banalnych, ale wręcz odwołujących się do instynktów i popędów, treści i form kulturowych. W konsekwencji kreowana i upowszechniana przez media kultura masowa - jako przeciwieństwo kultury wysokiej - kiczowata i skomercjalizowana, preferująca nihilizm egzystencjalny, moralny i konsumpcjonizm - to kultura pustki intelektualnej. W kulturze tej funkcjonuje się nie poprzez to, co się sobą intelektualnie i moralnie prezentuje, ale ,jak się jest” (dokładnie: jak się wygląda, w co się ubiera, co się je i z kim, gdzie i jak często bywa się, jakie bogactwa materialne posiada się). Współczesne media kreują społeczeństwo zanurzone w potoczności życia codziennego, którego jedyną formą propagowanego wzorca reakcji na problemy współczesnego świata jest pusty śmiech, a przejawem rozumu prezentujących go ludzi jest tzw. dowcip odwołujący się do instynktowo-popędowej sfery człowieka. Wytworzone zostały dla tak kształtowanego społeczeństwa właściwe mu struktury organizacyjne i formuly funkcjonowania. W działalności publicznej mężów stanu zastąpili politycy, a właściwie politykierzy, których jedynym celem jest, niezależnie od ceny i sensu tego rodzaju działań, „zdobyć władzę” lub „ją utrzymać”, a sama działalność polityczna jest jedynie „grą o władzę”. Filozofów zastępuja magowie i egzorcyści, uczonych wróżbici i tzw. eksperci; autorytety naukowe, artystyczne, moralne, a nawet religijne - celebryci.

Pojawiajacy się tu problem nie sprowadza się jedynie do tego, iż w ramach tak uformowanej kultury zachowania poszczególnych ludzi przybierają niemalże charakter automatyczny; ludzi, którzy żyją sobie w swoim świecie. Rzecz bowiem w tym, iż zostały ukształtowane - przez świadomych swych celów decydentów (przez tzw. elity liberałów) - ekonomiczne i strukturalne mechanizmy funkcjonowania nowego społeczeństwa, two-

\footnotetext{
${ }^{3}$ Przedstawicielami tego nurtu obok Odo Marquarda są m.in. Jacques Derrida, Richard Rorty, Jean-François Lyotard, Michel Foucault, Jean Baudrillard, Gilles Deleuze, Gianni Vattimo.
} 
rzone wedle wzorca starożytnego Rzymu: pod pozorami demokracji zostawcie nam rządzenie, a w zamian za nasz spokój, dostaniecie chleb i igrzyska.

\section{3. Środki masowego przekazu a zunifikowane spoleczeństwo globalne}

Realizowane przez decyzyjne centra polityczne Zachodu globalne imperium neoliberalne ${ }^{4}$, to nie tylko rzeczywistość tworzonych instytucji i wydarzeń. Wymaga ono także potwierdzenia, czy też uzasadnienia w sferze idei, a w szczególności uformowania przychylnej dla jego realizacji opinii społecznej ${ }^{5}$. Rola formowania takiej opinii we współczesnym podziale ról państwa globalnego w szczególny sposób przypada właśnie środkom masowego przekazu. Przy tym o ile udoskonalane technologie informacyjno-komunikacyjne niewątpliwie służą praktyce życia codziennego (czynią życie łatwiejszym), to jednocześnie są one doskonalszym narzędziem masowej manipulacji społeczeństwem. Zwłaszcza jeśli zważy się, że dzięki zastosowanym tzw. nowym mediom wykorzystanie wiedzy do manipulacji odbiorcami dokonywać się może w wymiarze globalnym. Biorąc pod uwagę chociażby aktualne możliwości techniczne i teleinformatyczne monitorowania ${ }^{6}$ poszczególnych ludzi, pojawia się pytanie o przyszłość, a mianowicie do czego może doprowadzić dalszy rozwój technologii informacyjno-komunikacyjnych? Czy przyszłość stanie się dopelnieniem wizji świata George’a Orwella?

Doskonalone technologie informacyjno-komunikacyjne umożliwiają zatarcie granic między tym co wirtualne, czyli fikcją, a tym co realne (mające potwierdzenie w rzeczywistości). Wytwór wirtualny np. sytuacji politycznej, ekonomicznej itp., przy wykorzystaniu

${ }^{4}$ Zarządzaniem gospodarką światowego imperium liberalnego pod dyktando Stanów Zjednoczonych Ameryki Północnej zajmuje się Ś wiatowa Organizacja Handlu, Międzynarodowy Fundusz Walutowy, Bank Swiatowy, a w wymiarze polityki NATO. Zob. co na ten temat pisze np. S. Amin, Wirus liberalizmu, przeklad A. Łukomska, Instytut Wydawniczy Ksiązka i Prasa, Warszawa 2007, s. 37. Zob. także A. L. Zachariasz, Globalizm jako formula realizacji imperium neoliberalnego, „इOФIA. Pismo Filozofów Krajów Słowiańskich" 2012, nr 12, s. 111-124. Cele strategiczne budowy globalnego imperium liberalnego określa quasi-rząd światowy stanowiący aktualnie tzw. grupę G-7 (od marca 2014 r.). W 1975 roku powstała tzw. grupa G-6, w skład której weszly Stany Zjednoczone, Francja, Wielka Brytania, Niemcy, Japonia, Wlochy. W 1976 r. dołączyła Kanada (G-7), a w 1997 Rosja (G-8). Udzial Rosji w G-8 został zawieszony 25.03.2014 r. w ramach „sankcji” za „nieposłuszeństwo” wobec ekspansyjnej polityki liberalnej Zachodu, której polem działań w Europie Środkowo-Wschodniej jest aktualnie Ukraina. Powodem było uznanie przez Rosję niepodległości Republiki Krymu (17.03.2014 władze Autonomicznej Republiki Krymu ogłosily Krym państwem niepodległym i zwrócily się do Rosji o przyjęcie w jej skład) i po podpisaniu umowy między Rosją a Republiką Krymu i miastem wydzielonym Sewastopol (18.03.2014) wlączeniu do Rosji jako podmiotów Krymskiego Okręgu Federalnego (21.03.2014). Organizatorem szczytu G-7 w 2014 r. była UE (odbył się w Brukseli 4.06.2014 r.).

${ }^{5} \mathrm{Na}$ temat kreowania przez media amerykańskie spolecznej akceptacji porządku polityczno-ekonomicznego zob. np. E. S. Herman, N. Chomsky, Manufacturing Consent. The Political Economy of the Mass Media, Pantheon Books, New York 2002 (I wyd. 1988), ss. 394.

${ }^{6}$ Współczesne technologie umożliwiają nie tylko na odległość, ale także ciągłe monitorowanie życia prywatnego, wręcz intymnego poszczególnych obywateli. Dzieje się to poniekąd za przyzwoleniem - często nieświadomym - ,monitorowanych”, gdyż warunkuje ono korzystanie ze wspólczesnych usług teleinformatycznych (telefon komórkowy, internet, nawigacja satelitarna, karty platnicze itp.). 
tzw. nowych mediów, uwiarygodniony odpowiednimi technikami, w odbiorze staje się nie tylko z uwagi na ów przekaz faktem (medialnym), ale zgodnie $\mathrm{z}$ intencją nadawcy przekonuje o prawdziwości wydarzeń na podstawie zawartych w przekazie treści (choć niemających potwierdzenia w rzeczywistości). W konsekwencji rzeczywiste zdarzenia zastępowane są tzw. faktami medialnymi (faktoidami), wydarzeniami czy też wypowiedziami formułowanymi na doraźny użytek osób (środowisk politycznych, ekonomicznych, obyczajowych) je kreujących. Najprostszą metodą uwiarygodniania treści tego rodzaju przekazów jest nie tylko masowe ich rozpowszechnienie przez tzw. wiodące agencje prasowe, ale także systemowe powielanie przez różne ośrodki przekazu informacji (w tym także przez krajowe i lokalne rozgłośnie radiowe, telewizję, internet, prasę). Pozwala to nie tylko na ich utrwalanie, ale również na budowanie przekonania, że wszyscy tak myślą i tak działaja, a proponowane przez ośrodki dyspozycyjne rozwiązania przedstawiane w tzw. mediach światowych są najlepszymi z możliwych.

O ile jednak instytucjonalny wymiar środków masowego przekazu znajduje swoje uzasadnienie w ich postępie technicznym, to ten jednak nie determinuje odpowiedzi na pytanie o to: co wyznacza określone działania dysponentów mediów masowych? Nie negując bynajmniej autonomiczności decyzji ich dysponentów, należałoby przyjąć, że te z zasady formułowane są bądź to jako realizacja pewnych idei (a więc w ramach myślenia wedle wartości), bądź też podejmowane są w kontekście faktycznego bycia człowieka w świecie, a więc jako odpowiedzi na to, co warunkuje człowieka w jego „codziennym byciu” na to, co „zdarza się". W omawianym tu wypadku nie sposób wykluczyć żadnej z tych możliwości. Niemniej uwzględniając zachodzące zmiany cywilizacyjne świata zachodniego, z dużym prawdopodobieństwem, jak sądzę, można zasadnie twierdzić, na co starałam się już wskazać, że decydenci środków masowego przekazu w formułowaniu celów swoich działań kierują się zarówno interesami ekonomicznymi (sprowadzającymi się do korzyści materialnych, pomnażania kapitału, dysponowania bogactwami naturalnymi itp.), jak i politycznymi (często łączonymi z interesami ekonomicznymi). Te determinowane są możliwościami skutecznego oddziaływania i spodziewanego zysku oraz ograniczane są ewentualnym ryzykiem utracenia dotychczasowych pozycji. Informacje stały się produktem o różnej wartości handlowej ${ }^{7}$. W zależności od ich ,producenta” są produktem podmiotów politycznych, koncernów przemysłowych, handlowych, jak też samych podmiotów medialnych. Reguły wolnego rynku umożliwiły nie tylko produkcję i sprzedaż informacji, ale także rozwój biznesu medialnego ${ }^{8}$.

Jednym ze środków kształtowania społeczeństwa politycznego zgodnie z wyobrażeniami wyznawców realizowanych idei politycznych, jak i preferowanych rozwiązań ekonomicznych jest medialne kreowanie powszechnej akceptacji społecznej. Służy ono również formowaniu określonej kondycji światopoglądowej oraz obyczajowej i moralnej

\footnotetext{
${ }^{7}$ Wykształciła się także na tym gruncie profesja tzw. infobrokera, osoby zajmującej się wyszukiwaniem informacji na zlecenie i ich odpłatnym udostępnianiu zleceniodawcy.

${ }^{8}$ Pozycję tzw. światowego barona medialnego osiągnąl Australijczyk Rupert Murdoch, wlaściciel jednej z największych na świecie korporacji prasowej, telewizyjnej i wydawniczej News Corporation, a także wloski polityk Silvio Berlusconi. Dzięki własnym mediom nie tylko udalo mu się zostać po trzykroć premierem, ale także promować swój wizerunek polityczny i utrzymywać poparcie wyborców w ramach działań public relations.
} 
społeczeństwa. W wymiarze politycznym, stanowi ono legitymizację podejmowanych działań np. wprowadzenia sankcji ekonomicznych, zwiększenia militaryzacji, czy też podejmowania interwencji zbrojnych. Media w tym procesie formowania opinii stanowią jednakże narzędzie pośrednie. Sąjedynie, jak zresztą wskazuje znaczenie używanego na ich określenie pojęcia, jedynie środkiem do celu. Celem bowiem zawsze są poszczególne jednostki, a właściwie jednostki funkcjonujące jako pewna zbiorowość. Za pomocą przekazów medialnych nie tylko kreuje się opinie korzystne dla realizacji określonych celów, ale także kreuje i utrwala uprzedzenia. Uzasadnia się chociażby wrogość wobec innych grup społecznych czy też całych społeczności. Sterowanie za pomocą treści przekazów rozpowszechnianych przez media, a właściwie należałoby tu użyć określenia (o)środki masowego oddziaływania, nie tylko skutkuje uzyskaniem odpowiedniej opinii publicznej czy też nastrojów społecznych. Często ich skutki (zamierzone) prowadzą do zaburzeń społecznych, protestów, (marionetkowych) ruchów społecznych czy wręcz rebelii itp. W efekcie dają niejako przyzwolenie decydentom politycznym np. do interwencji militarnej w imię tzw. obrony praw człowieka. Tak dzieje się zwłaszcza w sytuacjach, gdy dla doraźnych celów politycznych próbuje wykorzystać się różnice religijne lub też narodowe mające wsparcie w ideologiach i ruchach radykalnych, np. fundamentalistów islamskich bądź też formacji nacjonalistycznych. Działania tego rodzaju, wsparte propagandą medialną prowadzą z zasady do konfliktów, w tym także zbrojnych, które niejednokrotnie wykraczają poza ramy lokalne.

Skuteczność działań manipulacyjnych jest zależna nie tylko od intensywności, czy też profesjonalności środków masowego przekazu, ale w istotnej mierze od stanu intelektualnego i emocjonalnego samego społeczeństwa. Na ten składają się, oprócz przygotowania do rozumienia zachodzących w jego otoczeniu zjawisk, a więc wiedzy o świecie i o człowieku, wiedzy o społeczeństwie, przede wszystkim wyznawany system wartości, wyznawane idee, a także chociażby preferowane kryteria oceny, w tym także upodobania estetyczne. Problem w tym wypadku sprowadza się do pytania o to: na ile środki masowego przekazu wpływają na formowanie świadomości społecznej spełniającej możliwie wysokie standardy aksjologicznie kultury, w której funkcjonuje człowiek jako odbiorca informacji medialnej? Podejmując tę kwestię, zauważę, na co zwróciłam uwage już wcześniej, że współczesne media masowe nie kierują się bynajmniej wzorcami Oświecenia ani także wieku dziewiętnastego. Ich celem nie jest przekaz wiedzy naukowej ani także treści intelektualnych, zarówno kultury europejskiej, jak i innych kultur współczesnego świata. Te obszary traktuja jako margines swego działania. Media masowe w swoich przekazach preferują i wyraźnie propaguja, zgodnie ze swoją nazwą kulturę masową. Kultura ta kieruje się zasadą, iż odbiorca masowy to tzw. odbiorca przeciętny, a zatem nijaki; człowiek przeciętny, bez zdolności krytycznego myślenia, nastawiony na odbiór tego co łatwe w percepcji i rozumieniu (niewymagające namyshu). Taki odbiorca jest niewatpliwie podatny na przejmowanie ,gotowych myśli”. Przykładem tego sposobu przekazu informacji są choćby programy radiowe i telewizyjne oraz teksty drukowane, w tym wydawane specjalne czasopisma, zawierające gotowe opinie. Czynnikiem sprzyjającym manipulacji, a przemawiającym do przeciętnego odbiorcy, jest także odwoływanie się w przekazach medialnych do emocji i uczuć oraz do religii. Zabiegiem sprzyjającym formowaniu społeczeństwa realizującego się - a jednocześnie angażującego się - w banalności życia codziennego, jest aż nazbyt częste operowanie przez dziennikarzy 
współczesnych sensacją i techniką wywoływania szoku. Przy tym przedmiotem tego zabiegu są z zasady wydarzenia potoczne, jeśli nie wręcz pospolite. Należałoby jednakże podkreślić, że typowym przykładem formowania społeczeństwa „niemyślącego” i mającego zadowalać się konsumpcyjno-rozrywkowym stylem życia są-zwłaszcza obliczone na tzw. szerokiego odbiorce - programy telewizyjne w stylu kabaretowym, rozmowy z tzw. celebrytami, tzw. telenowele czy wręcz programy z gatunku scripted documentaries (dokument fabularyzowany/paradokument). Prezentują one wzorce zachowań na poziomie życia potocznego odwołujące się aż nazbyt często do niskiego poziomu intelektualnego. Propagowana kultura masowej przeciętności swoje uzasadnienie znajduje w haśle formułowanym przez polityków i dysponentów informacji: „lud głupi wszystko kupi”. Społeczeństwo kreowane w ten sposób ma być „Zabawną” masą bezwartościowych intelektualnie jednostek w myśl przesłania medialnego: im bardziej jesteś głupi, tym bardziej jesteś popularny i ,normalny”. W tej sytuacji należałoby postawić pytanie o zakres tego rodzaju dewastacji kultury, a przede wszystkim o to, na ile procesy, w których przeciętność jest chociażby normą rządzących (Breczko, 2013, s. 65-71), należy uznać za nieuchronne? Polityka tak rozumianej mediokracji jest niewatpliwie zagrożeniem dla tzw. kultury wysokiej i oznacza upadek społeczeństwa, zarówno w jego wymiarze intelektualnym, jak i politycznym. Przy tym należy zauważyć, że rezygnacja z życia wedle wartości i formowanie społeczeństwa wedle tego, co zdarza się oznacza nie tylko formowanie biernej do rządzenia masy społecznej, ale społeczeństwa jako całości. Jednostki pretendujące do uznawania ich za przedstawicieli tzw. elity, a zatem zabiegające o to by być wyróżnianym z ogółu społeczeństwa (np. ze względu na „dobre urodzenie”, stan posiadania, pełnione role społeczne, osiagnięcia itp.) często swoim poziomem ,bycia" nie odbiegają bowiem od mas, a co gorzej, same niekiedy ten poziom nie tylko masom narzucają, ale wręcz go prezentują.

\section{4. Środki masowego przekazu a polityka}

Media, jak już wskazałam, a przez nie dziennikarze jako pewna profesja, funkcjonują w każdym obszarze działania społeczeństwa współczesnego: zarówno w działaniach politycznych, ekonomicznych, kulturowych ( $\mathrm{tj}$. w modzie, sztuce, religii, w nauce itp.), jak i w życiu codziennym człowieka. W perspektywie realizacji i znaczenia środków masowego przekazu, a poprzez to i dziennikarstwa w społeczeństwie, dwa z wymienionych obszarów (nie negując znaczenia pozostałych) dla tych uwag wydają się być szczególne. Szczególność pierwszego z nich wynika z wagi prezentowanych przez nie zdarzeń dla społeczeństwa jako całości, a zwłaszcza wynikających stąd konsekwencji; drugiego natomiast dla bycia człowieka w społeczeństwie jako jednostki. Pierwszy z nich to obszar polityki, tj. przekazywania treści odnośnie wewnętrznego, jak i zewnętrznego (międzynarodowego) funkcjonowania państwa (uwzględniając wymiar prawny, administracyjny, gospodarczy itp.). Drugi to obszar życia prywatnego, względnie społecznego (wprawdzie nieodnoszący się bezpośrednio do sfery publicznej, choć w istotnej mierze determinujący ten pierwszy), sprowadzający się do relacjonowania, a właściwie propagowania określonego stylu życia. Ten drugi współcześnie sprowadzany jest do konsumpcjonizmu. Propagowany przez media dobrobyt materialny i wolność (wyboru spośród oferowanych 
produktów ${ }^{9}$ ) kształtuje człowieka ,jednowymiarowego", konsumenta, dążącego do zaspokajania wprawdzie podstawowych, choć jak twierdzi H. Marcuse, „fałszywych potrzeb" (Marcuse, 1991, s. 21-22). W systemie tych potrzeb staje się on sterowalny w swych wyborach, zwłaszcza gdy uwzględnimy możliwość zastosowania odpowiednich technik i współczesnej technologii monitorowania ${ }^{10}$. W rzeczywistości tej obywatel przyjął postawę konsumenta; stał się klientem, petentem czy też odbiorcą usług świadczonych przez państwo. Ograniczeniom społeczeństwa konsumpcyjnego podlegają także sami politycy. Nastawieni głównie na realizację własnych interesów, państwo, a zwłaszcza udział we władzy, pojmuja jako instytucję pozwalającą na zabezpieczenie wygodnego życia, jeśli nie wręcz na szybkie nagromadzenie bogactw materialnych. W grze o władzę postępują zgodnie z zasadami marketingu w warunkach wolnego rynku. Oznacza to, że programy wyborcze to jedynie oferty bez pokrycia lub wręcz reklamy handlowe. W realizację tych zabiegów w pierwszej kolejności - przy szerokim udziale dziennikarzy, rzeczników prasowych czy też tzw. spin doktorów i ekspertów od kształtowania pozytywnych relacji publicznych (tzw. piarowców) - angażują się zarówno media publiczne, jak i prywatne. W praktykach tych realizując tzw. plan „oczarowania” społeczeństwa, stosuje się różne techniki manipulacji. Przekazy medialne w swej formie, jak i treści nastawione są na kształtowanie u odbiorców stanów napięć emocjonalnych, np. kreowanie sytuacji permanentnego zagrożenia (kataklizmy, katastrofy, choroby, wypadki, przestępstwa, afery, kryzysy ekonomiczne, konflikty zbrojne itp.), wywoływanie sensacji, przywoływanie fobii narodowych, rasowych, ideologicznych itp. Przywoływane emocje tłumią racjonalność myślenia. Organizowane tzw. akcje medialne mają służyć kompromitowaniu przeciwników politycznych, a także utrwaleniu w pamięci odbiorców pożądanych przez nadawców przekazywanych treści. Celem tych zabiegów jest pozyskanie - dla prezentowanych interesów - akceptacji społecznej.

Innym zabiegiem stosowanym przez dysponentów środków masowego przekazu, a mającym na celu uzyskiwanie pożądanych propagandowo i politycznie efektów jest tzw. dozowanie informacji. Rezultatem tego rodzaju działań ma być zwiększanie zainteresowania oraz wzrost napięcia społecznego. Dozowanie informacji, a także tzw. ramowanie, łączone $\mathrm{z}$ ich kompilowaniem, tj. układaniem w pewien porządek, ma potwierdzać z góry założoną tezę, pod którą przygotowywany jest przekaz medialny. Przy tym, ramowaniu podlegają nie tylko zachodzące zdarzenia, ale także pewne procesy społeczne, instytucje, osoby, a także państwa. Informacje (szczególnie dotyczące polityki) podlegające ramowaniu przekazywane są z odpowiednią narracją i jako gotowy produkt sugerują z góry określoną reakcję społeczną (czy też opinię społeczna). Zabiegi te maja jednak na celu nie tylko wywoływanie określonych skojarzeń, ale także formowanie i utrwalanie pożądanych politycznie stereotypów. Tak np. Stany Zjednoczone Ameryki Północnej „ramowane” sąjako kraj potęgi, wolności i gwarancji niezależności (Street, 2006, s. 44).

9 „Wolny wybór - pisał H. Marcuse - spośród szerokiej różnorodności dóbr i usług nie oznacza wolności, jeżeli te dobra i usługi podtrzymują społeczną kontrolę nad życiem w znoju i strachu - to znaczy, gdy utwierdzają alienację". H. Marcuse, Cztowiek jednowymiarowy. Badania nad ideologia rozwiniętego spoleczeństwa przemyslowego, thum. S. Konopacki, Z. Koenig i in., Warszawa 1991, s. 25.

${ }^{10}$ Konsekwencją panowania technologicznego jest społeczeństwo totalitarne. Zob. co na ten temat pisze H. Marcuse, Czlowiek jednowymiarowy..., s. 183-212. 
Metoda selektywnego ujawniania (dozowania) informacji służyć może chociażby ochronie interesów rządzących (Street, 2006, s. 94-96). Jest ona rodzajem cenzurowania treści przekazów bez oficjalnego stosowania cenzury. W systemach demokratycznych nie jest ona oficjalnie stosowana, gdyż zgodnie z doktryną demokracji uznawana jest nie tylko za zbędną, ale wręcz szkodliwą. Nie oznacza to jednak, że pewne jej odmiany nie są stosowane. Zauważę bowiem, że cenzura może mieć różne formy, niejednokrotnie znacznie bardziej skuteczne niż tzw. cenzura oficjalna. Do jednej z nich należy zaliczyć tzw. system zarządzania informacją. Metodą prezentacji i rozpowszechniania określonych treści są w jej ramach przykładowo konferencje prasowe $\mathrm{z}$ udziałem dziennikarzy, którym przydziela się wyłączność na materiały informacyjne. Przy tym pojawiające się w mediach tzw. „przecieki”, z reguły sterowane przez osoby „pozostające przy władzy” (rządzący), czy też powiązane z nimi instytucje stwarzają wrażenie demokratycznej wolności, wskazując na wolność czy też niezależność mediów, a przy okazji uwiarygodniają ich profesjonalność i ich działanie na rzecz społeczeństwa. Rzecz w tym, że skomercjalizowanym mediom, jak można wnosić, nie tyle chodzi o przekaz informacji, ale o informacyjne panowanie, o władzę i to nie tylko ekonomiczną (rynek reklamy), ale i polityczną nad opinią publiczną. Nie bez racji środki masowego przekazu określa się mianem „czwartej władzy”. Aż nazbyt często, choć oczywiście nie sposób wykluczyć dziennikarzy zachowujących tradycyjne standardy, zadania mediów, zwłaszcza w obszarze polityki sprowadza się nie do przekazu informacji, ale do tzw. kreowania narracji. Znamiennym przykładem ,konstruktu medialnego" (Kellner, 1995, s. 198) była wojna w Zatoce Perskiej w 1999 r. Informacje z wojny w znaczącym wymiarze były nie tyle przekazem relacji wydarzeń ile ,produktem” rządu Stanów Zjednoczonych Ameryki Północnej. Były typowym produktem w dziedzinie public relations (Street, 2006, s. 28). Miały one w pierwszej kolejności uzasadniać prowadzoną przez rząd amerykański politykę i związaną z nią interwencję militarną wojsk amerykańskich.

Środki masowego przekazu, jak sądze, w istotnym wymiarze utraciły wymiar działań o charakterze społeczno-ideowym ${ }^{11}$ i coraz w większym stopniu przybierają postać działań ekonomiczno-politycznych. Niewiele w tej sytuacji wydaje się zmieniać we współczesnej rzeczywistości medialnej tzw. pluralizacja środków przekazu znajdująca swój wyraz w wielości i różnorodności nadawców medialnych, wielości kanałów telewizyjnych i radiowych, portali internetowych, dzienników prasowych, a nawet możliwości wypowiedzi przez tzw. internautów na forach internetowych, czy też blogach itp. Należy bowiem zauważyć, że tego rodzaju środki stwarzają jedynie pewien margines dla wolnych wypowiedzi. Funkcjonuja, co najwyżej, na zasadzie zaworu bezpieczeństwa i w globalnym wymiarze nie mają wpływu na kształtowanie opinii publicznej. W tej sytuacji, można by postawić pytanie, czy funkcjonujący w literaturze na ich określenie termin media społeczne (Kaczmarek-Śliwińska, 2001, s. 197-199), a który ma oznaczać społeczną kontrolę przekazów medialnych i możliwość społecznego ich tworzenia (czyli na rzecz dobra społecznego; pro publico bono) jest zasadny.

\footnotetext{
${ }^{11}$ Terminu tego używam $\mathrm{w}$ znaczeniu podkreślającym etosowy wymiar profesji dziennikarskiej, a zarazem w opozycji do dzialalności ideologicznej, jak i determinowanej interesami.
} 


\section{Czy możliwe jest spoleczeństwo wiedzy? O potrzebie nowego Oświecenia ${ }^{12}$ (uwagi końcowe)}

Uwzględniając chociażby dotychczasowe uwagi trudno byłoby uzasadniać tezę, że media masowe i prezentujący ich dziennikarze jako instytucje $\mathrm{i}$ jako pewna profesja w swej działalności są niezależni, kierują się wartością prawdy i działają wyłącznie na rzecz dobra publicznego. Zarówno dziennikarze, jak i stojące za nimi instytucje, działają na rzecz generowania zysków dla swoich pracodawców (właścicieli mediów); reprezentują różne grupy interesów (Ziemski, 2009, s. 53-60). Nie należy jednak wykluczać, że są dziennikarze niezależni, dla których wartością ich pracy jest obiektywny przekaz informacji. Niemniej, w skomercjalizowanych i upolitycznionych mediach wydają się oni stanowić nieliczną grupę, a być może nawet jedynie niewielki margines. Trudno byłoby także twierdzić, że wraz ze wzrostem ilości szkół dziennikarskich, w tym zakładów naukowych na uczelniach i prowadzonych kierunków studiów dziennikarskich, zmienia się na lepsze sposób funkcjonowania mediów i kształtowania społeczeństwa. Wynika to chociażby z faktu, iż niejednokrotnie sami nauczyciele nie są świadomi swej roli bądź też nie prezentuja wymaganej w tym względzie wiedzy i rozeznania w otaczającej ich rzeczywistości. Czy możliwe jest zatem społeczeństwo wiedzy w powszechnym systemie niewiedzy? Należałoby raczej przyjąć, że aby było to możliwe zmiana musiałaby nastapić u podstaw. Jej warunkiem w pierwszej kolejności jest uświadomienie stanu obecnej kultury masowej. Kolejnym warunkiem wydaje się być stworzenie mechanizmów prawnych i instytucjonalnych zabezpieczających wolność i niezależność mediów. W tym przede wszystkim uwolnienie mediów publicznych od grup nacisku politycznego czy też gry interesów politycznych i ekonomicznych, ale także ośrodków religijnych. Niewątpliwie także konieczna jest przemiana moralna tych, którzy ucza, czyli tych którzy są, czy też powinni być odpowiedzialni za kształt moralny społeczeństwa. Rzecz bowiem w tym, że grom interesów i myśleniu interesami (często doraźnymi) podlegają nie tylko dziennikarze, ale także ich nauczyciele. Innymi słowy przyszłość społeczeństwa zależeć będzie od tego czy znajdą się siły społeczne, które będą w stanie stawić opór degradacji świata działania wedle wiedzy i wartości, czy też społeczeństwu wystarczy jedynie reakcja na

\footnotetext{
${ }^{12}$ Oświecenie nie jest bynajmniej jednoznacznie oceniane przez filozofów XX wieku. Z krytyczną oceną tej epoki wystapili przede wszystkim przedstawiciele szkoly frankfurckiej Theodor W. Adorno oraz Max Horkheimer. Oświecenie postrzegali oni jako czas, w którym uformowaly się podstawy tzw. rozumu instrumentalnego oraz wiedzy instrumentalnej. Wiedza ta formowana w naukach przyrodniczych nakierowana byla na zapewnienie czlowiekowi panowania nad przyrodą. W naukach społecznych jej efektem było panowanie wąskich elit politycznych nad spoleczeństwem, czyli dwudziestowieczne totalitaryzmy. Z tych też względów Adorno i Horkheimer epokę tę, jak i uksztaltowany w niej rozum instrumentalny, oceniali negatywnie. Tej oceny nie podziela Jürgen Habermas. Filozof ten przezwyciężenie niebezpieczeństw wynikających z rozumu instrumentalnego widzi w racjonalizacji rzeczywistości społecznej oraz w tzw. działaniach komunikacyjnych. Ich celem byłoby znoszenie aporii i neutralizowanie konfliktów społecznych. Zob. M. Horkheimer, T. W. Adorno, Dialektyka Oświecenia, przel. M. Łukasiewicz, Wydawnictwo Krytyki Politycznej, Warszawa 2010, s. 13 i n., a także J. Habermas, Teoria dziatania komunikacyjnego, t. I: Racjonalność dzialania a racjonalność spoleczna, thum. A. M. Kaniowski, PWN, Warszawa 1999, ss. 669 oraz tenże, Teoria dzialania komunikacyjnego, t. II: Przyczynek do krytyki rozumu funkcjonalnego, thum. A. M. Kaniowski, PWN, Warszawa 2002, ss. 749.
} 
zdarzenia. Konkludując, można by stwierdzić, że aby społeczeństwo wiedzy i wartości mogło stać się udziałem współczesnego człowieka konieczne jest nowe Oświecenie.

\section{Bibliografia}

Amin S. (2007), Wirus liberalizmu, przekład A. Łukomska, Instytut Wydawniczy Książka i Prasa, Warszawa.

Breczko J. (2013), Mediokracja, w: Nieprzeciętność. Dylemat wolności, red. M. Szyszkowska, A. Rossmanith, Warszawa.

Habermas J. (1999), Teoria działania komunikacyjnego, t. I: Racjonalność działania a racjonalność spoleczna, thum. A. M. Kaniowski, PWN, Warszawa.

Habermas J. (2002), Teoria dziatania komunikacyjnego, t. II: Przyczynek do krytyki rozumu funkcjonalnego, thum. A. M. Kaniowski, PWN, Warszawa.

Herman E. S., Chomsky N. (2002), Manufacturing Consent. The Political Economy of the Mass Media, Pantheon Books, New York.

Horkheimer M., Adorno T. W. (2010), Dialektyka Oświecenia, przeł. M. Łukasiewicz, Wydawnictwo Krytyki Politycznej, Warszawa.

Kaczmarek-Śliwińska M. (2001), Media relations w erze social media, w: Media-czwarta wladza?, red. M. Gołda-Sobczak, W. Machura, J. Sobczak, t. II, Poznań-Opole.

Kellner D. (1995), Media Culture. Cultural studies, identity and politics between the modern and the postmodern, Routledge, London-New York.

Lojek J. (1988), Prasa dawnej Rzeczypospolitej, w: J. Lojek, J. Myśliński, W. Władyka, Dzieje prasy polskiej, Wyd. Interpress, Warszawa.

Marcuse H. (1991), Człowiek jednowymiarowy. Badania nad ideologia rozwiniętego spoteczeństwa przemystowego, thum. S. Konopacki, Z. Koenig i in., Warszawa.

Marquard O. (1994a), Apologia przypadkowości, tłum. K. Krzemieniowa, Warszawa.

Marquard O. (1994b), Rozstanie z filozofia pierwszych zasad, tłum. K. Krzemieniowa, Warszawa.

Street J. (2006), Mass media, polityka, demokracja, thum. T. D. Lubański, Wyd. UJ, Kraków.

Zachariasz A. L. (1983), Cztowiek a poznanie humanistyczne w filozofii Withelma Diltheya, Lublin.

Zachariasz A. L. (2009), Teza o końcu filozofii i granice jej zasadności a pytanie o przyszłość filozofii.

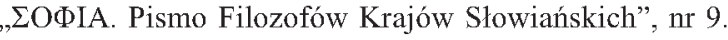

Zachariasz A. L. (2011), Refleksje o roli idei w ksztaltowaniu cywilizacji technicznej, „इOФIA. Pismo Filozofów Krajów Słowiańskich", nr 11.

Zachariasz A. L. (2012), Globalizm jako formuta realizacji imperium neoliberalnego, „इOФIA. Pismo Filozofów Krajów Slowiańskich", nr 12.

Ziemski A. (2009), Demokracja medialna, w: Demokracja w XXI wieku, red. M. Szyszkowska, Warszawa.

\section{Mass media in contemporary culture - information and enlightenment or manipulation?}

\section{Summary}

In the paper, the author formulates the thesis that in our times the role of journalism has been lost as the medium of informing about events, the popularisation of knowledge and forming positive cultural patterns. This happened as a result of a departure from a culture that refers to values. At present, the mass 
media create a consumerist culture, focused on short-term interests and living an ordinary life. This allows them to manipulate society for the sake of the interests of different groups. In order to overcome this state of affairs, which is unfavourable for society, it is necessary to return to the ideals of the Enlightenment and a culture appealing to values.

Key words: mass media, manipulation, culture, values, interests 